Egyptian Journal of Aquatic Biology \& Fisheries

Zoology Department, Faculty of Science,

Ain Shams University, Cairo, Egypt.

ISSN $1110-6131$

Vol. 23(1): 233 -243 (2019)

www.ejabf.journals.ekb.eg

\title{
Treatment of aquaculture waste effluent to be reused in fish culture in Egypt
}

\author{
Mohamed A. El-Sherbiny, Ghadir A. EL-Chaghaby* and \\ Yasser M. Abd El-Shafea \\ Regional Center for Food and Feed, Agriculture Research Center, Giza, Egypt. \\ * Corresponding Author:ghadiraly@yahoo.com
}

\section{ARTICLE INFO \\ Article History: \\ Received: Jan.4, 2019 \\ Accepted: Feb.5, 2019 \\ Online: Feb. 12, 2019}

Keywords:

Aquaculture

Effluent

Reused

Environment

Adsorbent

Treatment

\begin{abstract}
Aquaculture is currently the largest source of fish supply in Egypt. However, with this great productivity there has been an obsession with liquid waste and its impact on the environment. The aim of the present work is to make a preliminary trial to evaluate the ability of some low cost materials (sawdust, sawdust ash, granite powder, and crushed granite) to improve the quality of waste effluents resulting from recirculation aquaculture systems, and selecting the most efficient adsorbent to be applied at three different levels to verify which level is the most probable for waste effluent to be reused in fish culture. Total dissolved solids (TDS), electric conductivity (EC), salinity, dissolved oxygen (DO), turbidity, florin $(\mathrm{F})$, chlorine $(\mathrm{CL})$, phosphate $\left(\mathrm{PO}_{4}\right)$, sulphate $\left(\mathrm{SO}_{4}\right)$, ammonium $\left(\mathrm{HN}_{4}\right)$, nitirate $\left(\mathrm{NO}_{3}\right)$, nitrite $\left(\mathrm{NO}_{2}\right)$ were the evaluating parameter. Results from the adsorption experiment showed that the crushed granite was a promising adsorbent for aquaculture wastewater treatment. Accordingly, the effect of using different doses $(5 \mathrm{~g} / \mathrm{L}, 10 \mathrm{~g} / \mathrm{L}$ and $20 \mathrm{~g} / \mathrm{L}$ ) of crushed granite on water quality parameters was assessed and surface characteristics of cracked granite were determined using FTIR spectrophotometer for surface functional groups identifications, and X-ray diffraction (XRD) for mineralogical composition and nitrogen absorption for surface porous structure and surface area. Results revealed that crushed granite composed mainly of quartz and that $10 \mathrm{~g} / \mathrm{L}$ of crushed granite is the most probable level to be used with waste effluents for recirculation aquaculture systems.
\end{abstract}

\section{INTRODUCTION}

Water is a vital need for humans and all living organisms on earth. It is thus mandatory to preserve this important resource. Water quality is a key parameter in aquaculture industry. Fish is an inexpensive source of protein and an important cash crop in many regions of world (Bhatnagar and Devi, 2013). Optimum fish production from aquaculture majorly depends on integration between feeding and aquatic systems. Success in feeding system depends to a large extent on supplemental feeding (El-Sayed, 1999). At the same time, success in aquatic system depends on sufficient supply of water with proper physiochemical quality. 
Phosphorus is one of the supplemental feed ingredients that are essential in fish diet, yet phosphorous in aquaculture effluents is considered a source of pollution by some of the regulatory agencies (Lall, 1991).

Uneaten ration and unavailable dietary phosphorous in feces are the two primary contributors in phosphorous effluent from aquaculture ponds. Most of the current fish production practices in Egypt are carried out without recirculation or treatment of effluents prior to its disposal (Ghanem and Haggag, 2015). Conventional excavated earthen aquaculture farms in the northern Nile Delta are reported to cause increase in nutrients (nitrogen and phosphorus) and organic wastes, through the feeding inputs, leading to general deterioration of water quality (Sipaúba-Tavares et al., 2013; Sipaúba-Tavares and Santeiro 2013). According to Ghanem and Haggag (2015) 14250 ton /year Ammonia, 10688 ton/year nitrate and 404 ton/ year phosphorous are discharged to the Mediterranean Sea from Kafr ElSheikh alone. The cost of the environmental impact due to water pollution is relatively high with serious threatens to human health; increasing the severity of water scarcity problems, affecting the balance of aquatic ecosystems, economic development and social prosperity (Zyadah, 1996). Many attempts have been made to use different sorbents like activated carbon and alumina (Magriotis et al., 2014), yet the application of both adsorbents is limited by their high cost. Natural zeolites were tested and were proven to have a high affinity to metal ions yet it was found that natural zeolites needed to be modified before being used (Lemić et al., 2006; Motsi et al., 2009; Motsi, et al., 2011; Bao et al., 2013; and Itskos et al., 2015). Lakovleva (2018) stated that the final cost of zeolites is about $400-500$ USD per metric ton. Scientific researchers have searched for low cost-materials to be used for the treatment of polluted water like rice straw (Hegazy, 2008; and Ghanem and Haggag, 2015) cement klin dust (Hegazy et al., 2007). However, there are still some disadvantages concerning the known adsorbents. According to $\mathrm{Gu}$ et al., (2013) reported that bricks can remove phosphate and ammonium from aqueous solution with maximum adsorption of $3.8 \mathrm{mg} / \mathrm{g}$ for phosphate and $0.7 \mathrm{mg} / \mathrm{g}$ for ammonium. They have added that, it has rarely reported using one material to adsorb phosphate and ammonium simultaneously from aqueous solutions.

The adsorbents chosen for the present work are two locally available byproducts in Egypt with expect adsorption capacity owing to their composition. Granite is a general term for a type of igneous rock composed of a variety of minerals including quartz, potassium and plagioclase feldspars, crystalline ironbearing minerals (commonly amphibole and magnetite), and micaceous minerals with distinguished adsorptive capacities (Jan et al., 2008). Egypt is ranked the fourth respectively with a share of $4.3 \%$ and $6.6 \%$ of total world market of marble and granite (Hamza, et al., 2011). Sawdust is an abundant by-product of the wood industry that is either used as solid fuel for cooking or as packing material. It contains various organic compounds (lignin, cellulose and hemicellulose) with polyphenolic groups that create many active sites for adsorption (Rafatullah et al., 2010)

The aim of the present work is to make a preliminary trial to evaluate the ability of some low cost materials (sawdust, sawdust ash, granite powder, and crushed granite) to improve the quality of waste effluents resulting from recirculation aquaculture systems, and selecting the most efficient adsorbent to be applied at three different levels to verify which level is the most probable for waste effluent to be reused in fish culture. 


\section{MATERIALS AND METHODS}

\section{Experimental system and fish}

Mono sex Nile tilapia (Oreochromis niloticus) fingerlings were brought to Fish Experimental Unit in Regional Center for Food and Feed, Agriculture Research Center, Ministry of Agriculture, Giza, Egypt, from a fresh water commercial farm in Damietta Governorate. The experimental work was carried out in accordance with the national guidelines for care and use of laboratory animals and fish had received the utmost human care.

One hundred and thirty two mono sex Nile tilapia fingerlings (Oreochromis niloticus) of mean initial body weight $24.32 \pm 0.31 \mathrm{~g}$ from the stocked fish were randomly distributed into a 12 closed water recycle system (120 liter tanks), where each tank contained 11 fingerlings. The first 15 days of the experiment were considered as habituation period and thereafter the growth trials were carried out for 60 days. Diets (approximately $32 \%$ crude protein and 17.09 MJ estimated gross energy) were randomly assigned to the experimental units. Fish were hand fed the experimental diets at $3 \%$ of body weight for six days weekly, three times per day (Jauncey and Ross, 1982 and Coche, 1982).

The water flow rate out of each aquarium was $2 \mathrm{~L} / \mathrm{min}$ into a submerged biofilter after passing through a mesh net to remove solid impurities. Water was then collected in a common reservoir from which the filtered water was pumped up to the rearing units. Water used in the system was tap water stored for $24 \mathrm{~h}$ to be sure that water is free of chlorine. Water was continuously aerated by a blower. Five percent of the total water volume was renewed in the early morning to compensate the loss in water volume resulted from evaporation. A thermo-controlled electric heater was used to adjust water temperature about $24 \pm 1^{\circ} \mathrm{C}$. All the experimental treatments were conducted under an artificial photo period equal to natural light/darkness period (12h light:12h darkness).

\section{Waste water samples}

At the end of the growth trial eighteen wastewater samples were collected in $0.5 \mathrm{~L}$ bottles for each sample from the biofilter tanks using the technique proposed by Bradley et al., (2016). Three samples were transferred directly using thermally insulated container to water analysis lab and stored in refrigerators at approximately $4{ }^{\circ} \mathrm{C}$. The other fifteen samples were directly conducted with five different adsorbents (each three samples represent a treatment).

\section{Adsorbents}

The tested adsorbents included: Zeolite, sawdust, sawdust ash, granite powder and crushed granite. Zeolite extra pure synthetic was purchased from Sigma-Aldrich. Sawdust was obtained from local furniture factory. Sawdust ash was obtained by combusting the sawdust at $500^{\circ} \mathrm{C}$ for $4 \mathrm{~h}$ in muffle furnace. Granite powder and crushed granite were obtained from Shaq Al Thobaan.

\section{Wastewater treatment experiments}

Batch experiments (15 samples) were conducted by adding $1 \mathrm{~g}$ of each adsorbent to $100 \mathrm{ml}$ (level $10 \mathrm{~g} / \mathrm{l})$ wastewater in separate conical flasks and the flasks were capped. Flasks were then placed in a shaking water bath set at $100 \mathrm{rpm}$ at room temperature and left overnight. The water samples were then filtered and the adsorbents were removed. The samples were then subjected for physiochemical analysis. 
The same batch experimental steps were then repeated using the most efficient adsorbent at three different levels $(5 \mathrm{~g} / \mathrm{l}, 10 \mathrm{~g} / \mathrm{l}$ and $20 \mathrm{~g} / \mathrm{l})$. Each level was done in triplicate.

\section{Wastewater analysis}

Standard Methods for the Examination of water and west water (APHA, 2005), were used to determine aquaculture recirculation wastewater quality characteristics ( $\mathrm{pH}$ value), turbidity value (NTU), electrical conductivity (EC) value $(\mu \mathrm{s} / \mathrm{cm})$, total dissolved solids (TDS) $(\mathrm{mg} / \mathrm{L})$, salinity $(\mathrm{mg} / \mathrm{L})$ and dissolved oxygen (DO) $(\mathrm{mg} / \mathrm{L})$.

Inorganic Anions (Phosphate, sulphate, chlorine, nitrate and nitrite concentration $(\mathrm{mg} / \mathrm{L})$ were determined according to (USEPA 300.1, 1997 \& USEPA $300,1993)$ by using Thermo Scientific DionexICS $-5000^{+}$Ion Chromatography supplied with Dionex Ion Pac AS23 Analytical column protected by Dionex Ion Pac AS 23 Guard Column for anions determination.

Ammonium $\left(\mathrm{NH}_{4}\right)$ and florin concentration $(\mathrm{mg} / \mathrm{L})$ were determined according to (ASTM D6919-03, 2003) and by using Thermo Scientific DionexICS-5000 ${ }^{+}$Ion Chromatography supplied with DionexIonPacCS12A Analytical column protected by Dionex Ion PacCS 12A Guard Column for cations determination.

\section{Adsorbent characterization}

The different surface characteristics of cracked granite were determined using FTIR spectrophotometer (Thermo Scientific, USA), X-ray diffraction (XRD) for mineralogical composition and nitrogen absorption procedure by Brunauer-EmmettTeller (BET) method for surface porous structure and surface area.

\section{Statistical analysis:}

Data are presented as means \pm standard error (SE). The obtained data were subjected to one way analysis of variance (ANOVA) using the linear model (GLM) of SAS (SAS institute, 1991). Then means are compared adopting Duncan's new multiple range test $(\mathrm{P}<0.05)$.

\section{RESULTS AND DISCUSSION}

The physiochemical results of recirculation aquaculture effluent and the effect of the five adsorbent tested materials are shown in Table (1). The data revealed that the untreated recirculation aquaculture waste effluent has low water quality compared with desirable and acceptable range stated by Bradley et al., (2016) in term of dissolved oxygen (DO) and for desirable limit in term of nitrite. As the dissolved oxygen (DO) was significantly low $(2.66 \mathrm{mg} / \mathrm{l})$ compared to permissible value (DO) $>5 \mathrm{mg} / \mathrm{l}$. while, nitrite was higher $(0.19 \mathrm{ppm})$ than desirable range $(0-0.1$ ppm).

All tested adsorbents had significantly decreased Turbidity, ammonia and nitrate load and improved the DO, compared to untreated waste effluent (Table 1). Sulphate and nitrite load were effectively decreased using different adsorbents except sawdust ash when compared to untreated waste effluents. Florin level was not affected by different treatments. Yet, in overall the statistical analysis of the different parameters shows that crushed granite significantly improved the studied waste effluent quality compared to the other adsorbents. Crushed granite and sawdust ash were the only two adsorbents to achieve the permissible value of DO (5.87 and 5.09 $\mathrm{mg} / \mathrm{l}$ respectively). Dissolved oxygen (DO) is a very basic requirement for aquaculture species. It is usually the first limiting factor to occur in pond culture. The very low levels of DO are lethal after long term exposure; and at lower dissolved 
oxygen, only small fish can survive short-term exposures. For the cultivation of Nile tilapia the recommended DO should be $>5 \mathrm{mg} / \mathrm{L}$.

Table 1: Adsorbents effect on circulation aquaculture waste effluent physiochemical parameters. ${ }^{1}$

\begin{tabular}{|c|c|c|c|c|c|c|c|c|}
\hline Parameter & $\begin{array}{c}\text { Untreated } \\
\text { waste } \\
\text { effluent } \\
\text { from bio } \\
\text { filter tank }\end{array}$ & Zeolite & sawdust & Sawdust ash & $\begin{array}{c}\text { Granite } \\
\text { powder }\end{array}$ & $\begin{array}{c}\text { Granite } \\
\text { crushed }\end{array}$ & $\begin{array}{c}\text { Desirable } \\
\text { range }\end{array}$ & $\begin{array}{c}\text { Acceptable } \\
\text { range }\end{array}$ \\
\hline $\mathrm{TDS}(\mathrm{mg} / \mathrm{l})$ & $692 \pm 9^{\mathrm{d}}$ & $454 \pm 20^{\mathrm{a}}$ & $522 \pm 25^{\mathrm{b}}$ & $1301 \pm 50^{\mathrm{e}}$ & $581 \pm 25^{\mathrm{c}}$ & $567 \pm 28^{\mathrm{c}}$ & ------- & ------- \\
\hline $\mathrm{EC}(\mu \mathrm{S} / \mathrm{cm})$ & $1422 \pm 40^{\mathrm{d}}$ & $930 \pm 25^{\mathrm{a}}$ & $1066 \pm 45^{\mathrm{b}}$ & $2661 \pm 100^{\mathrm{e}}$ & $1190 \pm 50^{\mathrm{c}}$ & $1151 \pm 57^{\mathrm{bc}}$ & $60-2000$ & $30-5000$ \\
\hline $\mathrm{Salinity} \%$ & $0.67 \pm 0.03^{\mathrm{c}}$ & $0.50 \pm 0.03^{\mathrm{a}}$ & $0.50 \pm 0.01^{\mathrm{a}}$ & $1.40 \pm 0.02^{\mathrm{d}}$ & $0.60 \pm 0.03^{\mathrm{b}}$ & $0.57 \pm 0.02^{\mathrm{b}}$ & $0-10 \%$ & \\
\hline $\mathrm{DO}(\mathrm{mg} / \mathrm{l})$ & $2.66 \pm 0.035^{\mathrm{F}}$ & $4.27 \pm 0.05^{\mathrm{c}}$ & $3.60 \pm 0.1^{\mathrm{e}}$ & $5.09 \pm 0.09^{\mathrm{b}}$ & $4.00 \pm 0.1^{\mathrm{d}}$ & $5.87 \pm 0.12^{\mathrm{a}}$ & $>5$ & \\
\hline Turbidity $(\mathrm{NTU})$ & $112.70 \pm 3^{\mathrm{e}}$ & $18.00 \pm 2^{\mathrm{b}}$ & $23.67 \pm 1.5^{\mathrm{c}}$ & $11.00 \pm 1^{\mathrm{a}}$ & $40.00 \pm 2^{\mathrm{d}}$ & $8.67 \pm 0.5^{\mathrm{a}}$ & & \\
\hline $\mathrm{F}(\mathrm{ppm})$ & $0.218 \pm 0.017^{\mathrm{a}}$ & $0.410 \pm 0.009^{\mathrm{d}}$ & $0.312 \pm 0.006^{\mathrm{c}}$ & $4.367 \pm 0.015^{\mathrm{e}}$ & $0.970 \pm 0.01^{\mathrm{e}}$ & $0.24 \pm 0.02^{\mathrm{b}}$ & $0.1-1.5$ & $<3.0$ \\
\hline $\mathrm{Cl}_{(\mathrm{ppm})}$ & $72.22 \pm 0.66^{\mathrm{c}}$ & $105 \pm 1^{\mathrm{d}}$ & $58 \pm 1^{\mathrm{a}}$ & $246 \pm 1^{\mathrm{e}}$ & $65 \pm 1^{\mathrm{b}}$ & $59 \pm 1^{\mathrm{a}}$ & $60-100$ & -------- \\
\hline $\mathrm{PO}_{4}(\mathrm{ppm})$ & $68 \pm 1^{\mathrm{d}}$ & $97 \pm 1^{\mathrm{e}}$ & $17 \pm 1^{\mathrm{c}}$ & $1.65 \pm 0.05^{\mathrm{a}}$ & $12 \pm 1^{\mathrm{b}}$ & $2.26 \pm 0.11^{\mathrm{a}}$ & $0.01-2.0$ & $<3.0$ \\
\hline $\mathrm{SO}_{4}(\mathrm{ppm})$ & $41.29 \pm 1^{\mathrm{e}}$ & $9.18 \pm 1^{\mathrm{a}}$ & $14 \pm 1^{\mathrm{b}}$ & $101 \pm 2^{\mathrm{F}}$ & $27.54 \pm 1^{\mathrm{c}}$ & $30.78 \pm 2^{\mathrm{d}}$ & $0-1000$ & \\
\hline $\mathrm{NH}_{4}(\mathrm{ppm})$ & $27 \pm 1^{\mathrm{e}}$ & $22 \pm 1^{\mathrm{c}}$ & $20 \pm 1^{\mathrm{b}}$ & $15 \pm 1^{\mathrm{a}}$ & $25 \pm 1^{\mathrm{d}}$ & $24 \pm 1^{\mathrm{d}}$ & & \\
\hline $\mathrm{NO}_{3}(\mathrm{ppm})$ & $12 \pm 2^{\mathrm{c}}$ & $5 \pm 2^{\mathrm{b}}$ & $1.33 \pm 0.05^{\mathrm{a}}$ & $2 \pm 0.05^{\mathrm{a}}$ & $1.33 \pm 0.05^{\mathrm{a}}$ & $1.33 \pm 0.05^{\mathrm{a}}$ & -------- & $<90$ \\
\hline $\mathrm{NO}_{2}(\mathrm{ppm})$ & $0.19 \pm 0.05^{\mathrm{c}}$ & $0.15 \pm 0.05^{\mathrm{b}}$ & $>0.0001^{\mathrm{a}}$ & $0.24 \pm 0.01^{\mathrm{d}}$ & $>0.0001^{\mathrm{a}}$ & $>0.0001^{\mathrm{a}}$ & $0.0-0.1$ & $<4.0$ \\
\hline 1
\end{tabular}

${ }^{1}$ Values are the mean of triplicate $n=3$, means with different superscripts letters in the same row are significantly different $(\mathrm{P}<0.05)$.

Crushed granite had high efficiency in decreasing the average value of turbidity $(92.3 \%)$ followed by the other adsorbents. Turbidity in waters decreases the available light needed for photosynthesis by phytoplankton and lead to the growth of undesirable organisms. Turbidity can shield food organisms, clog filters, causes damage and fish stress. Because many suspended solids will settle out in ponds or canals, another major concern besides turbidity itself is the amount of suspended particles that can potentially settle out Sediments from highly turbid source water may fill ponds and canals within a few months. Sedimentation can also smother eggs of some species in ponds used for natural reproduction (Zweig et al., 1999).

Sawdust ash followed by crushed granite was significantly able to decrease the average value of phosphate in circulation aquaculture waste effluent to $1.65 \mathrm{ppm}$ and $2.65 \mathrm{ppm}$, respectively. According to Stone and Thomforde, (2004) the acceptable phosphate level in fish culture is $<3 \mathrm{mg} / \mathrm{l}$ (Bhatnagar and Devi, 2013). Different authors stated that the accumulation of phosphorous in natural or artificial water bodies is considered to be major cause of eutriopcation which cause excessive growth of algae, as well as sharp decrease of dissolved oxygen and finally fish toxicity ( Montalvo, et al., (2011) and Gu, et al., (2013). In this study both sawdust ash and crushed granite was efficiently able to remove phosphate from circulation aquaculture waste effluent with a removing capacity reached 97.6 and 96.7 percentage, respectively.

Crushed granite, granite powder and sawdust decreased both nitrate and nitrite load to $1.33 \mathrm{ppm}$ and $>0.0001$ (the detection limit of the instrument) with average removal efficiency $88.9 \%$ and $100 \%$ respectively. Nitrite is formed due to bacterial conversion (Nitrosommonas) of ammonia. Nitrite under normal condition is converted to nontoxic nitrate.

In case nitrite concentration is high in water, brown blood disease occurs lead to fish suffocation despite adequate oxygen concentration in water (Ghasemi et al., 2016). 
Sawdust ash lowered the average value of ammonia to $15 \mathrm{ppm}$ with average removal efficiency $44.4 \%$ followed by sawdust $25.9 \%$ and zeolite $18.5 \%$. Crushed granite and granite dust had minor effect on ammonia removal efficiency (11 and 7\%). This result differs from what have been established by Mumpton, (1985) how stated that zeolite was able to remove upto $97 \%$ of ammonia produced in aquaculture. This contradiction in zeolite effectiveness have been explained by Ghasemi et al., (2016) how stated that zeloite ion exchange efficiency is affected by many factors such as zeolite type, pore size and particle size, chemical composition of the contaminated water as well as other factors such as water salinity. According to Lemić, et al, (2006); Motsi, et al., (2009), Motsi, et al., (2011), Bao, et al (2013) and, Itskos et al., (2015); unmodified zeolites have poorer adsorption capacity than modified one. Lakovleva (2018) have stated that the cost of zeolite modification can vary from 400 to 500 USD per metric ton.

Based on the results of adsorption experiment and considering the availability and cost of the adsorbents, the crushed granite was chosen as a representative adsorbent for aquaculture wastewater treatment.

Accordingly, the effect of using different doses of crushed granite on water quality parameters was assessed and the results are given in Table (2).

Table 2: Effect of different doses of crushed granite on water quality parameters 1

\begin{tabular}{|l|l|l|l|l|l|}
\hline Parameter & Granite 5g/l & Granite 10g/l & Granite 20g/l & Untreated & PROBABILITY \\
\hline PH & $8.062 \pm 0.15^{\mathrm{a}}$ & $7.005 \pm 0.25^{\mathrm{c}}$ & $7.697 \pm 0.25^{\mathrm{b}}$ & $7.059 \pm 0.35^{\mathrm{c}}$ & $\mathrm{P}<0.01$ \\
\hline TDS & $572.7 \pm 27^{\mathrm{a}}$ & $567 \pm 28^{\mathrm{a}}$ & $557.3 \pm 12^{\mathrm{a}}$ & $692 \pm 9^{\mathrm{b}}$ & $\mathrm{P}<0.001$ \\
\hline EC & $1205 \pm 56^{\mathrm{a}}$ & $1151 \pm 83^{\mathrm{a}}$ & $1195 \pm 56^{\mathrm{a}}$ & $1422 \pm 40^{\mathrm{b}}$ & $\mathrm{P}<0.01$ \\
\hline Salinity & $0.6 \pm 0.03^{\mathrm{a}}$ & $0.6 \pm 0.02^{\mathrm{a}}$ & $0.6 \pm 0.025^{\mathrm{a}}$ & $0.8 \pm 0.04^{\mathrm{b}}$ & $\mathrm{P}<0.001$ \\
\hline DO & $4.22 \pm 0.24^{\mathrm{c}}$ & $5.867 \pm 0.125^{\mathrm{a}}$ & $5.280 \pm 0.25^{\mathrm{b}}$ & $2.663 \pm 0.35^{\mathrm{d}}$ & $\mathrm{P}<0.001$ \\
\hline Turbidity & $10.5 \pm 0.55^{\mathrm{a}}$ & $9.00 \pm 0.5^{\mathrm{a}}$ & $10.00 \pm 0.5^{\mathrm{a}}$ & $77.00 \pm 3^{\mathrm{b}}$ & $\mathrm{P}<0.001$ \\
\hline $\mathrm{F}(\mathrm{ppm})$ & $0.255 \pm 0.013^{\mathrm{c}}$ & $0.240 \pm 0.02^{\mathrm{b}}$ & $0.30 \pm 0.015^{\mathrm{d}}$ & $0.218 \pm 0.017^{\mathrm{a}}$ & $\mathrm{P}<0.01$ \\
\hline $\mathrm{Cl}$ & $40.00 \pm 2^{\mathrm{a}}$ & $52.40 \pm 2.6^{\mathrm{b}}$ & $55.70 \pm 2.8^{\mathrm{c}}$ & $72.22 \pm 0.66^{\mathrm{d}}$ & $\mathrm{P}<0.001$ \\
\hline $\mathrm{PO} 4$ & $17.75 \pm 0.89^{\mathrm{c}}$ & $2.257 \pm 0.11^{\mathrm{a}}$ & $7.360 \pm 0.4^{\mathrm{b}}$ & $68 \pm 1^{\mathrm{d}}$ & $\mathrm{P}<0.001$ \\
\hline $\mathrm{SO}_{4}$ & $37.45 \pm 1.86^{\mathrm{b}}$ & $17.35 \pm 0.87^{\mathrm{a}}$ & $18.85 \pm 0.94^{\mathrm{a}}$ & $41.29 \pm 1^{\mathrm{c}}$ & $\mathrm{P}<0.001$ \\
\hline $\mathrm{NH}_{4}$ & $12.56 \pm 0.63^{\mathrm{a}}$ & $12.55 \pm 0.58^{\mathrm{a}}$ & $12.77 \pm 0.63^{\mathrm{b}}$ & $14.12 \pm 0.71^{\mathrm{c}}$ & $\mathrm{P}<0.001$ \\
\hline $\mathrm{NO}_{3}$ & $1.370 \pm 0.07^{\mathrm{a}}$ & $1.26 \pm 0.03^{\mathrm{a}}$ & $0.51 \pm 0.02^{\mathrm{a}}$ & $12 \pm 1^{\mathrm{b}}$ & $\mathrm{P}<0.001$ \\
\hline $\mathrm{NO}_{2}$ & $0.19 \pm 0.01^{\mathrm{c}}$ & $<0.0001^{\mathrm{a}}$ & $0.05833 \pm 0.0015^{\mathrm{b}}$ & $0.1933 \pm 0.05^{\mathrm{d}}$ & $\mathrm{P}<0.001$ \\
\hline
\end{tabular}

${ }^{1}$ Values are the mean of triplicate $n=3$, means with different superscripts letters in the same row are significantly different $(\mathrm{P}<0.05)$.

Table 2 shows that, different dose from crushed granite have nearly the same significant adsorbent efficiency regarding total dissolved solids (17.24-19.5\%), electric conductivity (15.3-19.05\%), salinity (25\%), turbidity (86.4-88.3\%) and nitrate (88.6-95.75\%). All tested adsorbents had significantly improved the DO with both 10 and 20 gram crushed granite per liter achieved the permissible value of DO (>5 mg /L). Fig.1. illustrates that $10 \mathrm{~g}$ crushed granite per liter has significantly decreased the average value of phosphate in circulation aquaculture waste effluent by $96.7 \%$ compared to 20 and $5 \mathrm{~g} /$ liter (89.1 and $73.9 \%$ respectively). Also 10 and 20 g crushed granite were significantly able to adsorb 58 and $54.3 \%$ respectively of sulfate in circulation aquaculture waste effluent Fig. 2. 


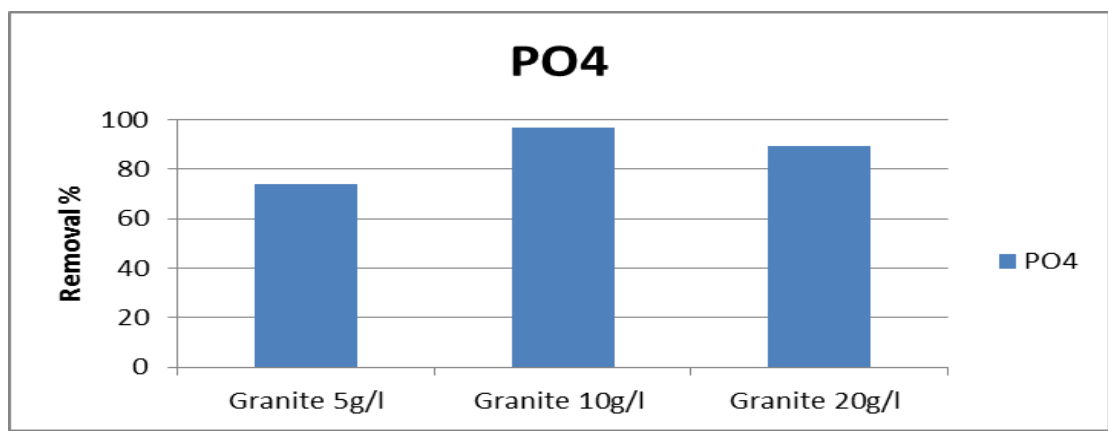

Fig.1: Effect of different doses of crushed granite on phosphate removal percentage.

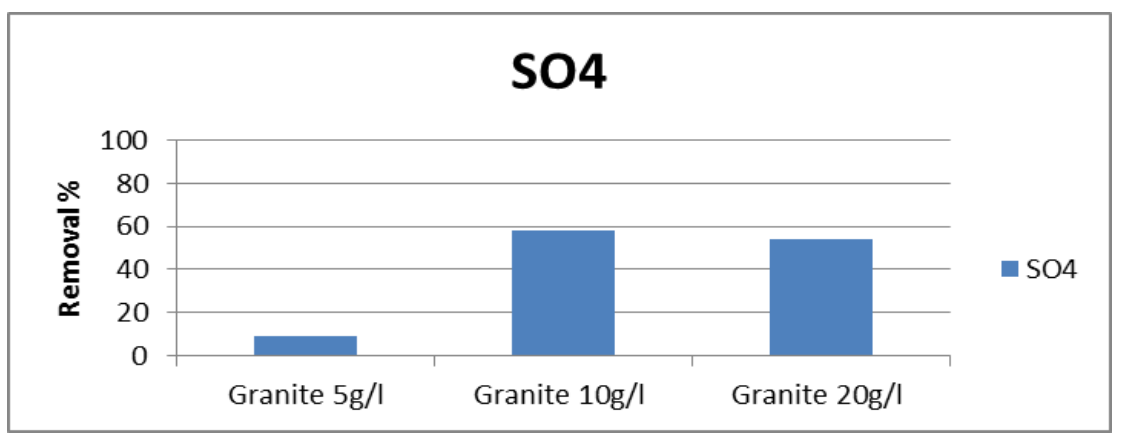

Fig 2: Effect of different doses of crushed granite on sulphate removal percentage.

Fig.3. shows the effect of different dose from crushed granite on nitrite, nitrate and ammonia. Ten gram crushed granite has significantly removed nitrite completely from circulation system waste effluent. Twenty gram crushed granite was able to remove $69.8 \%$ of nitrite, while five gram crushed granite was able to remove only $1.7 \%$ of nitrite. While different doses of crushed granite nearly have the same removing capacity of nitrate. On the contrary different dose from crushed granite have minor significant ammonia removal efficiency, with ten gram crushed granite per liter being the most efficient dose $(11.1 \%)$. From the above results it is clear that the highest removal percentages were obtained at an adsorbent dose of $10 \mathrm{~g} / \mathrm{l}$.

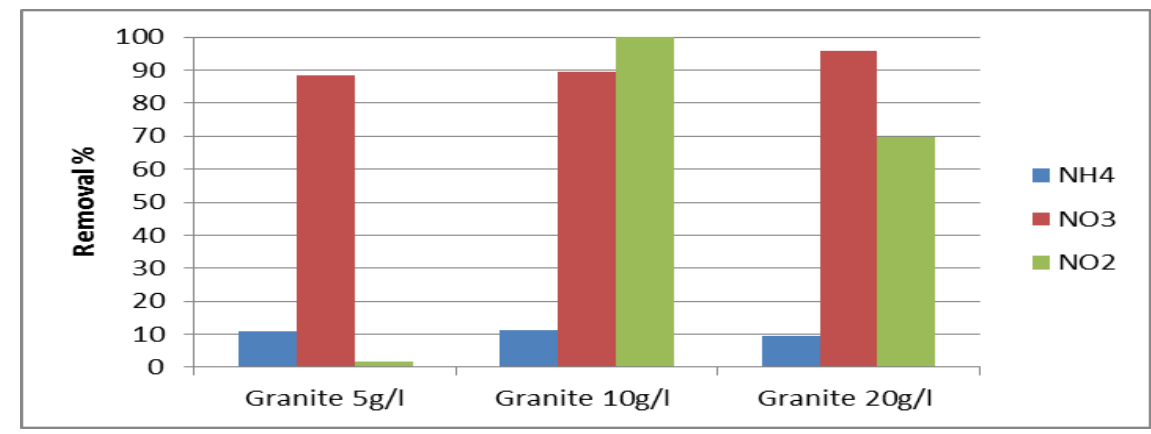

Fig 3: Effect of different doses of crushed granite on ammonia, nitrite, and nitrate removal percentage.

\section{Crushed granite characterization}

The crushed granite was characterized by different tools to get more info about its structure. The BET plot of crushed granite is given in Fig.4. The surface area, total pore volume and average pore size of the crushed granite were found to be 
$22.156 \mathrm{~m}^{2} \mathrm{~g}^{-1}, 0.014 \mathrm{~g} \mathrm{~cm}^{-3}$ and $1.283 \mathrm{~nm}$, respectively. The average Particle radius was also determined to be approximately $61.545 \mathrm{~nm}$.

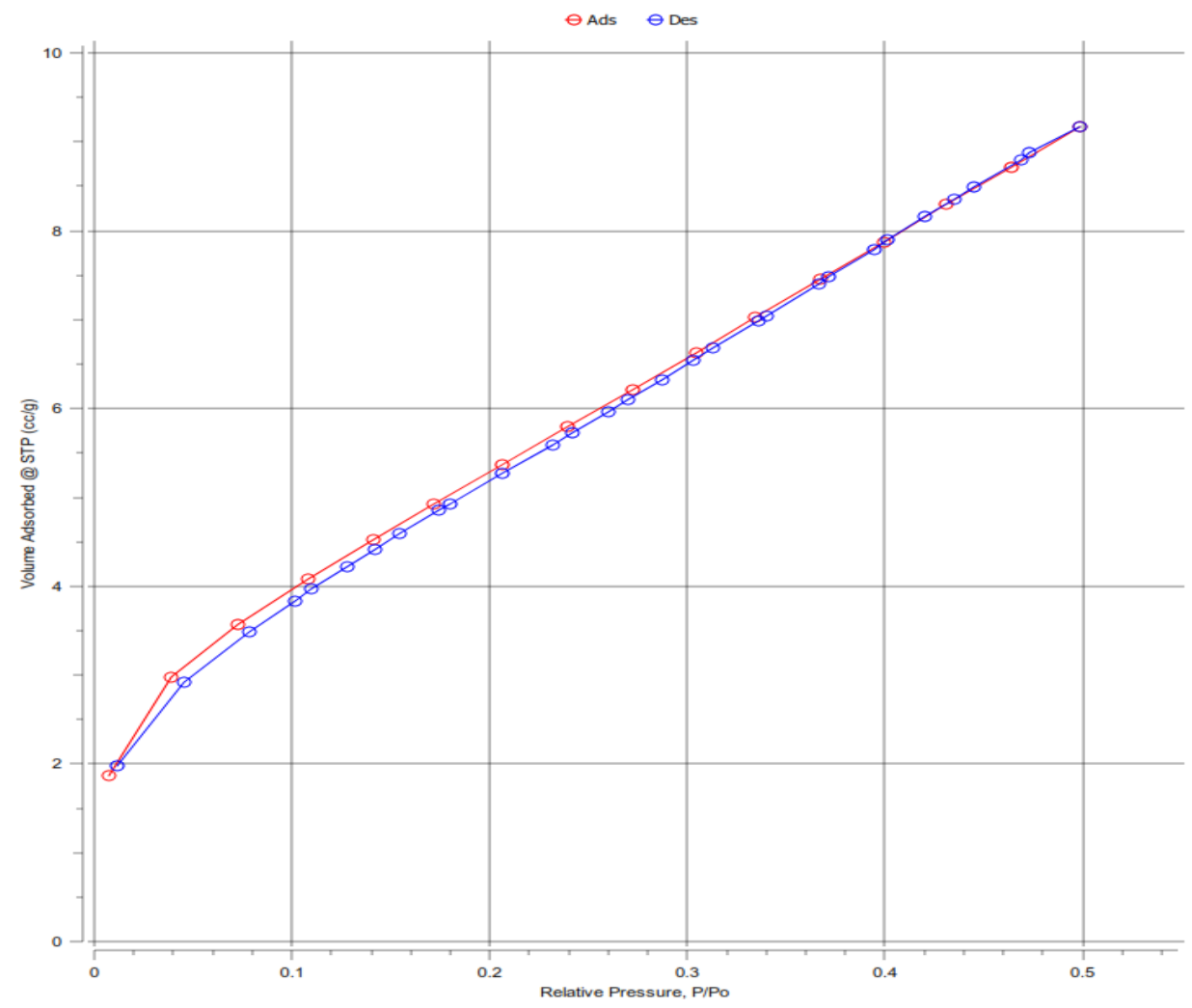

Fig 4. BET plot of crushed granite.

It is known that, the adsorption ability of an adsorbent is usually related to its own surface area, which depends on pore volume and size (Wu et al., 2014). Thus the high surface area of crushed granite along with its pore volume and small size indicate its enhanced adsorption ability.

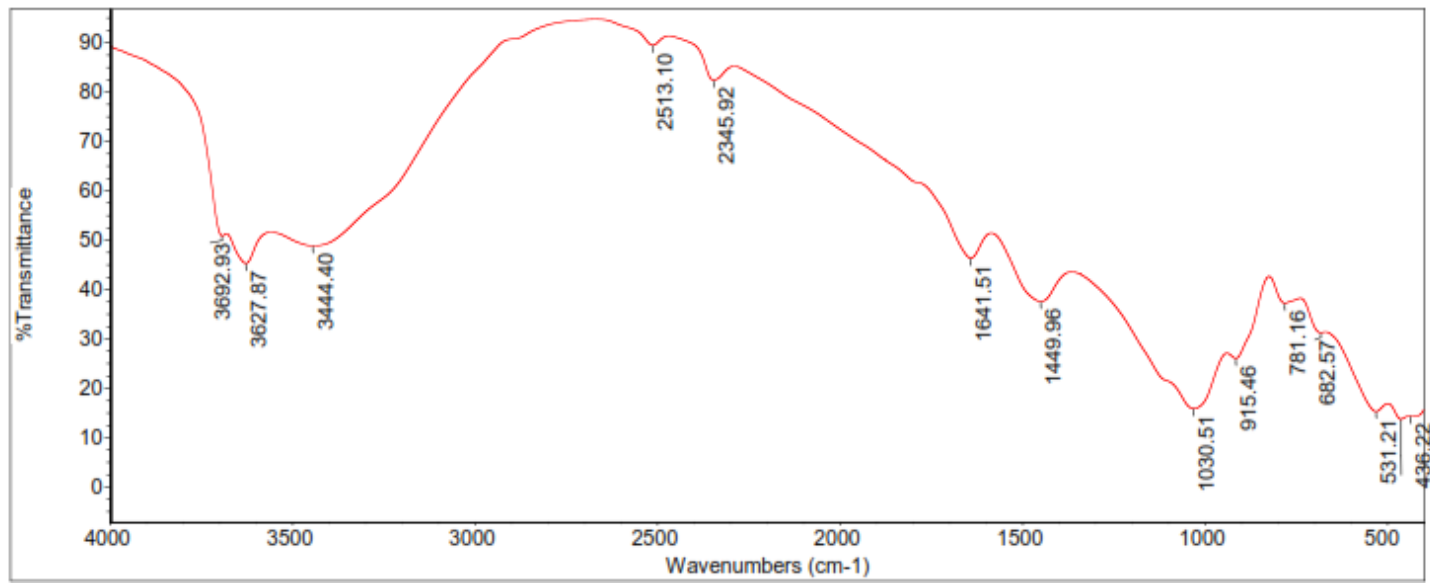

Fig. 5: FTIR spectrum of crushed granite.

The FTIR spectrum of crushed granite (Fig.5) shows that the region 781.16 $436.22 \mathrm{~cm}-1$ indicating the presence of quartz. Also, a peak at $1030.51 \mathrm{~cm}^{-1}$ can be assigned to characteristic bands of silicates which are mostly related to stretching vibrations of Si-O or Al-O (Aroke, Abdulkarim and Ogubunka, 2013). The peaks at 3680,3580 , and $3400 \mathrm{~cm}^{-1}$ are due to $\mathrm{OH}$ bond stretching for $\mathrm{Al}-\mathrm{OH}$ and $\mathrm{SiOH}$. The band at $1030.51 \mathrm{~cm}^{-1}$ corresponds to the oxygen-bridging $\mathrm{Si}-\mathrm{O}-\mathrm{Si}$ asymmetric 
stretching and non oxygen-bridging $\mathrm{Si}-\mathrm{O}$ stretching in granite (Aroke, Abdulkarim and Ogubunka, 2013). The presence of these functional groups of crushed granite could act as effective adsorption sites for contaminants, and thus increase its adsorption capacity. The presence of Silica groups on the crushed granite is very important for the adsorption especially that of phosphate ions. The phosphate groups can form strong hydrogen-bonded complexes with the silanols of the silica surface (Murashov and Leszczynski, 1999).

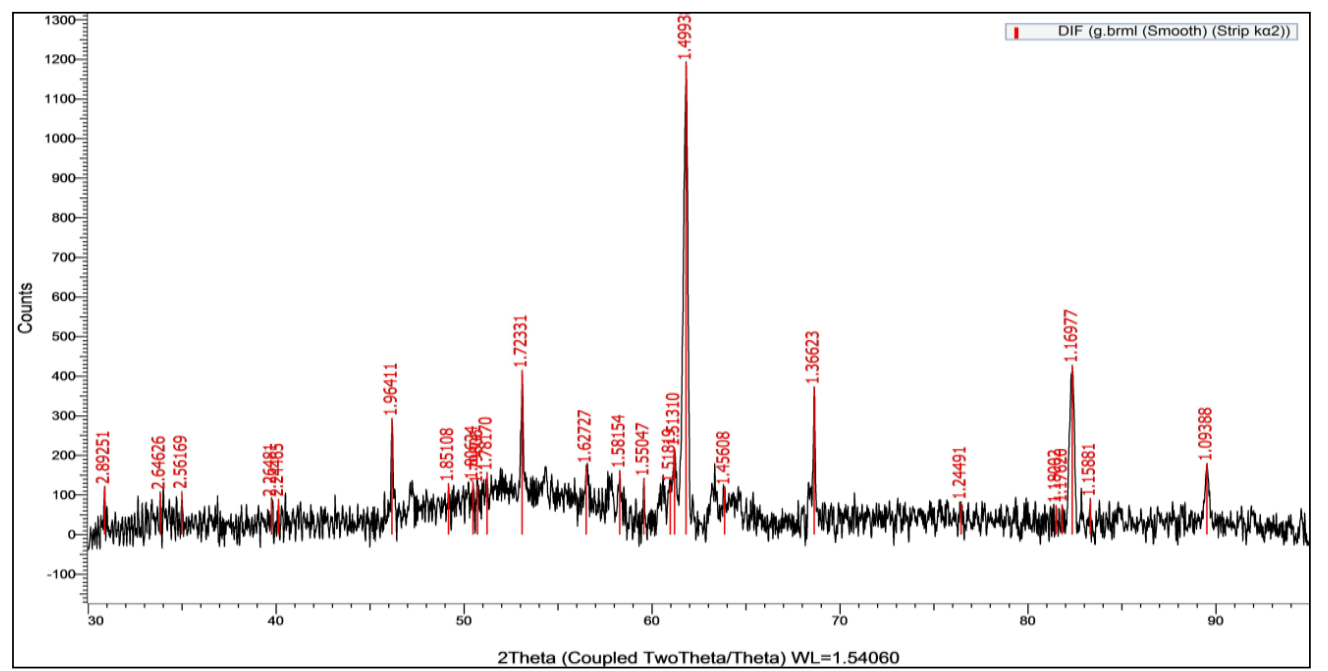

Fig. 6: XRD diagram shows the main content of crushed granite.

The XRD of crushed granite (Fig. 6) shows that the granite mainly contains quartz ( $\mathrm{SiO} 2)$ which is in accordance with previous studies showing that granite is mainly composed of quartz, calcite (CaCO3) , $\mathrm{Al} 2 \mathrm{O} 3$ (alumina) and other minerals (Hamza et al., 2011; El- Hinnawi and Abayazeed 2011 and Gao et al., 2017).

\section{CONCLUSION}

According to the Egyptian strategy there is a continuous effort to develop wastewater management plans for aquaculture to protect the environment and the natural resources. In this study crushed granite gave promising results on its adsorbent ability on circulation aquaculture waste effluents with $10 \mathrm{~g} / \mathrm{L}$ being the most efficient dose. This will not only constitute an added value to aquaculture industry but will also lead to manage the undesirable residues from granite industry. More field studies are needed to see the effect of different environmental factors on crushed granite adsorbent capability.

\section{REFERENCES}

APHA, (2005). Standard methods for the examination of water and waste water, $21^{\text {st }}$ ed. American Public Health Association, Washington, DC, USA.

Aroke, U.O.; Abdulkarim, A. and Ogubunka, R.O. (2013). Fourier-transmission Infrared Characterization of Kaolin, Granite, Bentonite \& Barite. ATBU journal of environmental technology, 6 (1): 399-404.

ASTM. D6919-03, (2003). "Standard Test Method for Determination of Dissolved Alkali and Alkaline Earth Cations and Ammonium in Water and Wastewater by Ion Chromatography", ASTM International, West Conshohocken, PA, 2003 
Bao, W.; Liu, L.; Zou, H.; Gan, S.; Xu, X.; Ji, G.; Gao, G. and Zheng, K. (2013). "Removal of $\mathrm{Cu} 2+$ from Aqueous Solutions Using Na-A Zeolite from Oil Shale Ash," Chinese J. Chem. Eng., 21(9): 974-982.

Bhatnagar, A. and Devi, P. (2013). Water quality guidelines for the management of pond fish culture. International journal of environmental sciences, 3(6): 1980-2009.

Bradley, J. A.; Amit Sinha, N. S.; Reed G. W.; Mike D. and Brian E. H. (2016).How to Collect Your Water Sample and Interpret the Results for the Fish Pond Analytical Package. Arkansas Water Resources Center, University of Arkansas System Division of Agriculture.

Coche, A.G. (1982). Cage culture of tilapias. In: the Biology and Culture of Tilapia, eds. R.S.V. Pullin and R.H. Lowe-McConnel. Manila, Philippines: ICLARM. Cited by Lovell, T. (1989).

El-Hinnawi, E. and Abayazeed, S.D. (2011). Characterization of dimension stone sawing sludge in Egypt. Journal of Applied Science. 11(6): 1019-1025.

El-Sayed, A.F.M. (1999). Alternative dietary protein sources for farmed tilapia, Oreochromis spp. Aquaculture, 179: 149-168.

Gao, X.; Yuan, B.; Yu, Q.L. and Brouwers, H.J.H. (2017). Characterization and application of municipal solid waste incineration (MSWI) bottom ash and waste granite powder in alkali activated slag. Journal of Cleaner Production, 164: 410-419.

Ghanem, A. and Haggag, M. (2015). Assessment of the feasibility of using filter made of rice straw for treating aquaculture effluents in Egypt. Resources and Environment, 5 (5): 135-145.

Ghasemi, Z.; Sourinejad, I.; Kazemian, H. and Rohani, S. (2016). Application of zeolites in aquaculture industry: a review. Reviews in Aquaculture 0: 1-21.

Gu, D.; Zhu, X.; Vongsay, T.; Huang, M.; Song, L. and He, Y. (2013). Phosphorous and nitrogen removal using novel porous bricks incorporated with wastes and minerals. Pol. J. Environ. Stud. 22 (5): 1349-1356.

Hamza, R. A.; El-Haggar, S. and Khedr, S. (2011). Marble and Granite Waste: Characterization and Utilization in Concrete Bricks. International Journal of Bioscience, Biochemistry and Bioinformatics. 286-291.

Hegazy, B. (2008) "A simple technology for industrial wastewater treatment", Journal of Applied Sciences Research. 4(4): 397-402.

Hegazy, B.; El-Khateeb, M. A.; El-adly, A. and Kamel, M.M. (2007). "Low-cost waste water treatment technology", Journal of Applied Sciences. 7: 815-819. DOI: $10.3923 /$ jas.2007.815.819.

Itskos, G.; Koutsianos, A.; Koukouzas, N. and Vasilatos, C. (2015). "Zeolite development from fly ash and utilization in lignite mine-water treatment," Int. J. Miner. Process., 139: 43-50.

Jan, Y.L.; Wang, T.H.; Li, M.H.; Tsai, S.C.; Wei, Y.Y. and Teng, S.P. (2008). Adsorption of Se species on crushed granite: A direct linkage with its internal iron-related minerals. Applied Radiation and Isotopes, 66(1): 14-23.

Jauncey, K. and Ross, B.R. (1982). "A guide to tilapia feeds and feeding". Institute of Aquaculture, University of Striling. FKA, Scotland, V.K.L., 9: 68.

Lakovleva, E. (2018). Novel sorbents from low-cost materials for water treatment. Ph.D. Thesis., Mikkeli- University. Finland.

Lemić, J.; Kovacević, D.; Tomasević-Canović, M.; Kovacević,D.; Stanić, T. and Pfend, R. (2006). "Removal of atrazine, lindane and diazinone from water by organozeolites.," Water Res., 40( 5): 1079-85. 
Lall, S.P. (1991). Digestibility, metabolism and excretion of dietary phosphorous in fish. In: C.B. Cowey and C.Y. Cho (editors), "Nutritional strategies and Aquaculture waste". Proceedings of the first International Symposium on Nutritional Strategies and Aquaculture Waste, 2-6 June (1990). Guelph, Canada, University of Guelph, Ont., Canada, pp. 21-36.

Magriotis, Z. M.; Leal, P. V. B.; de Sales, P. F.; Papini, R. M.; Viana,P. R. M. and Arroyo, P. A. (2014). "A comparative study for the removal of mining wastewater by kaolinite, activated carbon and beta zeolite," Appl. Clay Sci., 91-92: 55-62.

Montalvo, S.J.; Guerrero, L.E.; Milan, Z. and Borja, R. (2011). Nitrogen and phosphorous removal using a novel integrated system of natural zeolite and lime. J. Environ. Sci. Heal. Pt. A. 46: 1385.

Motsi, T.; Rowson, N. A. and Simmons, M. J. H. (2009). "Adsorption of heavy metals from acid mine drainage by natural zeolite," Int. J. Miner. Process., 92 (1-2): 42-48.

Motsi, T.; Rowson, N. A. and Simmons, M. J. H. (2011). "Kinetic studies of the removal of heavy metals from acid mine drainage by natural zeolite," Int. J. Miner. Process., 101(1-4): 42-49.

Mumpton, F.A. (1985). "Using zeolites in agriculture" In: Innovative biological technologies for lesser developed countries (part 10 of 15).

Murashov, V. V. and Leszczynski, J. (1999). Adsorption of the Phosphate Groups on Silica Hydroxyls: An ab Initio Study. The Journal of Physical Chemistry A., 103(9): 1228-1238.

Rafatullah, M.; Sulaiman, O.; Hashim, R. and Ahmad, A. (2010). Adsorption of methylene blue on low-cost adsorbents: a review. Journal of hazardous materials. Elsevier B.V., 177(1-3): 70-80.

Stone, N. M. and Thomforde, H. K. (2004). Understanding your fish pond water analysis report', University of Arkansas Cooperative Extension Program Printing Service. p.34. Available at: http://www.ianrpubs.unl.edu/liveg.pdf.

Sipaúba-Tavares, L. H. and Santeiro, R. M. (2013)."Fish farm and water quality management", Acta Scientiarum. Biological Sciences, 35(1): 21-27. Doi:10.4025/actascibiolsci.v35i1.10086.

SAS, (1991). SAS / STAT User's guide. SAS Institute, Cary, NC, USA, 1028.

Sipaúba-Tavares, L. H.; Millan, R. N. and do Amaral, A. A. (2013). "Influence of management on the water quality and sediment in tropical fish farm", Journal of Water Resource and Protection, 5: 495-501. Doi.org/10.4236/jwarp.2013.55049.

USEPA Method 300 (1993). "The Determination of Inorganic Anions in Water by Ion Chromatography"; USEPA Cincinnati, Ohio, 1993.

USEPA Method 300.1, (1997). "The Determination of Inorganic Anions in water by Ion Chromatography”, USEPA, Cincinnati, Ohio, 1997.

Wu, L.; Zhang, X.; Liu, D.; Peng, H. and Long, T. (2014). Activated Carbons Derived from Livestock Sewage Sludge and their Absorption Ability for the Livestock Sewage', IERI Procedia. Elsevier B.V., 9: 33-42.

Zyadah, M. (1996). Occurrence of heavy metals in some fish sediment and water samples from river Nile within Damietta Governorate. Proceedings of the $6^{\text {th }}$ International Conference of Environmental protection is a must, Alex, 21-23 May 1996, 929-942.

Zweig, D.; Morton, R. and Stewart, M. (1999). Source Water Quality for Aquaculture, The International Bank for Reconstruction and Development. doi: 10.1596/0-8213-4319-X. 